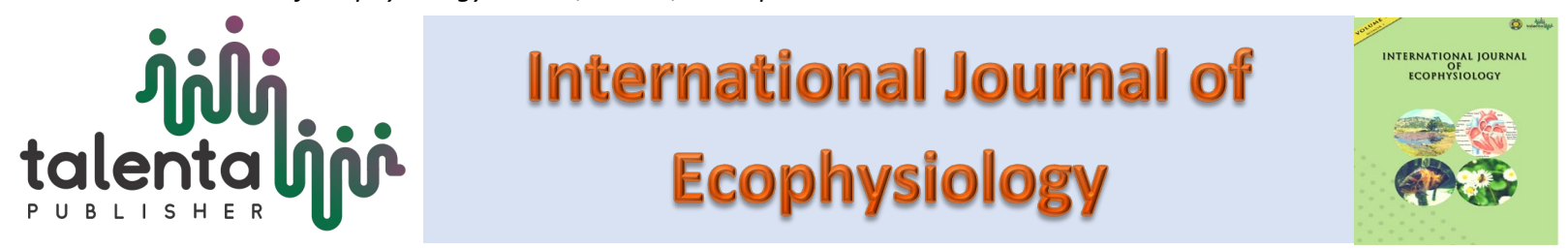

\title{
Isolation and Degradation Study on Carbosulfan Containing Pesticide of Biosufactant-Producing Bacteria From Belawan Sumatera
}

\author{
Frans Grovy Naibaho', Erman Munir ${ }^{2}$ and Nunuk Priyani ${ }^{2}$ \\ ${ }^{1}$ Undergraduate student, Department of Biology, Fakulty of MIPA, Universitas Sumatera Utara, Jln. \\ Bioteknologi No. 1 Kampus USU, Padang Bulan, Medan 20155 \\ ${ }^{2}$ Department of Biology, Fakulty of MIPA, Universitas Sumatera Utara, Jln. Bioteknologi No.1, Kampus \\ USU, Padang Bulan, Medan 20155.
}

\begin{abstract}
Uncontrol use of synthetic pesticide causes environmental pollution and leaves its residue in soil and water. The objective of this research was to obtain bacterial isolates capable of producing biosurfactant from Belawan North Sumatera and to observe their biosurfactant activities as well as their potential in degrading of carbosulfan pesticide. Bacteria were isolated using selective medium, Bushnell-Hass Agar (BHA) containing 2\% of pesticide with carbosulfan as the active compound. The result showed that all bacterial isolates were able to grow on the medium and consumed carbosulfan as the carbon sourc. The highest cell population was shown by isolate Sp.1 with total count was $7.6 \times 10^{9}$ $\mathrm{CFU} / \mathrm{ml}$. The highest biosurfactant activity was shown by isolate $\mathrm{Sp} .6$ with the volume of emulsion was $5.627 \mathrm{~cm}^{3}$, meanwhile the highest production of biosurfactant shown by Sp.7 with concentration was $54.6 \mathrm{ppm}$. Two isolates, Sp.1 and Sp.6 were selected for further test to study their abilities in carbosulfan degradation. Both isolates were able to degrade carbosulfan completely after 21 days of incubation.
\end{abstract}

Keyword: Carbosulfan, biodegradation of pesticide, bioremediation, biosurfactant

Received 10 June, 2020 | Revised 28 July, 2020 | Accepted 30 August, 2020

\section{$1 \quad$ Introduction}

The use of pesticide to control pest and plant diseases still plays an important role in agriculture. It is required to improve both quality and quantity of the crop [1]. Sutamihardja [2] reported that pesticide, mainly insecticide application is an important part of plant protection. Yet, unwise application of pesticide including insecticide may cause serious problem since its residue polluted soil and both surface and ground water [3].

Pesticide residual pollution has various negative effects on life. Its accumulation result in agricultural land pollution and if it enters the food chains its toxic compound may cause severe

*Corresponding author at: J. Bioteknologi No. 1 Kampus Univ. Sumatera Utara, Padang Bulan, Medan, Indonesia 
diseases such as mutation, cancer as well as Chemically Acquired Deficiency Syndrome (CAIDS) [4].

Pesticide residue that pollutes the environment consists of hydrocarbon compounds. These compounds are quite stable in the environment and are toxic to organisms [5]. Carbosulfan included in carbamat group and is an active compound of pesticide which is widely used mainly in Sumatera Utara. It has an aromatic ring structure, and is a potent inhibitor of cholinesterase, an enzyme vital for functioning of the central nervous system. As a result, it is highly toxic to mammals with $50 \%$ lethal dose ranging from $90-250 \mathrm{mg} / \mathrm{kg}$ in rat. Therefore its concentration should be strictly controlled.

An effective and safe method to heal the polluted area is bioremediation technique. It is a technique to remedy, to remove pollution from the environment using microorganism. The microbe functions as the agent of remediation through adsorption, and oxidation and reduction reactions. To metabolism those compounds, microorganism secretes biosurfactant to increase their solubility which in turn will be attacked by hydrolytic enzymes. Bertrand [6] reported that microorganism with high production of biosurfactant capable of degrading aromatic hydrocarbon effectively.

Bacteria isolated from the sea abled to produce biosurfactant and to degrade an aromatic hydrocarbon naphthalene [7]. Furthermore some bacteria isolated from Belawan sea, Sumatera Utara were reported to degrade glifosate [8]. Parra [9] said that biosurfactant-producing bacteria could be readily found in area contaminated by aromatic hydrocarbon compounds. This study reports the potency of bacterial isolates from Belawan sea in degrading carbosulfan.

\section{Materials and Methods}

\section{Chemicals}

All chemicals were from sigma except the pesticide was bought from a local market. Biosurfactan concentration was determined by analyzing rhamnose concentration using spectrophotometer while carbosulfan residue was detected using Gas Chromatography ZB-1 $(30 \mathrm{~m} \times 0.25 \mathrm{~mm} \times 0.25 \mu \mathrm{m})$ at $300^{\circ} \mathrm{C}$.

\section{Isolation of microorganism and characterization}

The Biosurfactant-producing bacteria were isolated from Belawan sea, a big public sea port in Medan Sumatera Utara. The water sample was inoculated on Bushnel Haas Agar medium containg pesticide as the carbon source. The growing colonies were purified and characterized morphologically and biochemically. All colonies were maintained at slant agar media. 
All colonies were characterized based on their shape, edge, color, elevation of colonies, cell's shape and arrangement as well as Gram staining. Simple biochemical test including ability to metabolize citrate, starch, gelatin. hydrogen sulfide and catalase were performed to obtained isolates which were different each other.

\section{Estimation of cell population}

Bacterial cell population was determined by Standard Plate Count method. $0.1 \mathrm{ml}$ of each culture was spread on plate count agar (PCA) and was incubated for $24 \mathrm{hrs}$. The bacterial growth was observed on day 7, 14 and 21th of incubation. The number of colonies was counted using colony counter based on following formula:

Number of cells $=$ Numbers of colony $x \frac{1}{\text { dilution factor }}(\mathrm{CFU} / \mathrm{ml})$

\section{Biosurfactant activity}

The activity of biosurfactant secreted by each isolate was measured using Drop Collapsing Test method [10]. For this purpose, the supernatant and n-kexan $(1: 1 \mathrm{v} / \mathrm{v})$ were taken ino a tube vortexed for $2 \mathrm{~min}$ and left for $24 \mathrm{hrs}$. In this case we used $2 \mathrm{ml}$ of supernatant and $2 \mathrm{ml}$ of $\mathrm{n}$ hexan. The volume of emulsion which is formed was measured.

\section{Quantification of Biosurfactant Concentration}

To analyze the concentration of biosurfactant which is produced during incubation time, a standard curve of rhamnose was used. A serial of rhamnose dilution in sodium bicarbonate $\left(\mathrm{NaHCO}_{3}\right) \quad 0.05 \mathrm{M}, 2 \mathrm{ml}$ each $(10,50,100$ dan $200 \mathrm{ppm})$, was added with $3.6 \mathrm{ml}$ orcinol solution, heat to boil, let them cool at room temperature for about $15 \mathrm{~min}$. Measure their absorbance ant $\chi 421 \mathrm{~nm}$. The regression line equation of rhamnose standard curve was determined using Least Square method.

\section{Bacterial growth condition for biosurfactant production}

A $24 \mathrm{hrs}$ old culture was used as inoculum. Two $\mathrm{ml}$ of inoculum of each isolate, which is equal to Mc Farland standard was inoculated into $98 \mathrm{ml}$ of BHB medium containing $2 \%$ of ccarbosulfan pesticide. The cultures were incubated in water bath shaker at $150 \mathrm{rpm}, 30^{\circ} \mathrm{C}$, and in dark condition for 21 days. The cultures were centrifuged at $6,000 \mathrm{rpm}$ for $10 \mathrm{~min}$. four $\mathrm{ml}$ of supernatant was added with $2 \mathrm{ml}$ of diethylether and shake vigorously to extract the biosurfactant. The ether layer was separated carefully. The extraction was repeated three times. The ether layer was dried and dissolved into $2 \mathrm{ml}$ of $\mathrm{NaHCO}_{3} 0,05 \mathrm{M}$ solution, vortexed and added with $3.6 \mathrm{ml}$ of orcinol solution. The solution is heated it, let it cool for $15 \mathrm{~min}$ and measure its absorbance at $\chi 421 \mathrm{~nm}$. The quantification of biosurfactant concentration was done on 7,14 , and 21 days of incubation. 


\section{Biodegradation of carbosulfan by local isolates}

Bacterial degradation of carbosulfan was studied in mineral BHB medium containing $2 \%$ of carbosulfan pesticide. Twenty $\mathrm{ml}$ of inoculum of each isolate which is equal to Mc Farland standard was added aseptically into $980 \mathrm{ml}$ of BHB medium. The cultures were grown in waterbath shaker at $150 \mathrm{rpm}$, temperature of $30^{\circ} \mathrm{C}$ in the dark condition for 21 days. Cultures were centrifugated at $6,000 \mathrm{rpm}$ for 10 minutes, the supernatant was used for analysing the residue of carbosulfan.

Culture supernatant $(300 \mathrm{ml})$ was taken into separated funnel, added with $100 \mathrm{ml}$ of dichloromethane and shake vigorously. Two layers were formed, the dichloromethane layer was separated. The extraction was repeated twice by addition of $50 \mathrm{ml}$ of dichloromethane and shake well. Dichloromethane was evaporated, added with a mixture of isooctane : toluene (9:1) to get $3 \mathrm{ml}$ volume. The carbosulfan concentration was analyzed using Gas Chromatography Varian CP-3800 column ZB-1 (30m x 0,25mm x 0,25 $\mu \mathrm{m})$ with detector ECD, column temperature $200-270^{\circ} \mathrm{C}$, detector temperature $300^{\circ} \mathrm{C}$, injector temperature $280^{\circ} \mathrm{C}$

\section{Result and Discussion}

\section{Characters of obtained isolates}

Nine isolates were able to grow on BHA medium indicating that those bacteria could metabolize carbosulfan and use the compound as the carbon source. They varied in colony morphology such as: colony shape were circular and irregular; edge of colony are entire, undulate and lobate; elevation were flat and convex. Base on microscopic observation it was shown that among 9 isolates, 7 isolates were Gram negative while the rest are Gram positive. Five isolates are cocci while 4 others are bacilli. The result of biochemical test gave evident that those isolates are different.

\section{Bacterial Cell Population}

The bacterial growth during 21 days of incubation was shown in Figure 1 below. It was known that all bacterial isolates increased in cell numbers at different rate. The initial population was $2.0 \times 10^{6}$ cells $/ \mathrm{ml}$.

The highest cell growth on day 7 th was shown by isolate $\mathrm{Sp} .7$ which was $46 \times 10^{8} \mathrm{CFU} / \mathrm{ml}$ while isolate Sp. 9 showed the lowest one which was $22 \times 10^{8} \mathrm{CFU} / \mathrm{ml}$. It was assumed that isolate Sp. 7 was able to adapt more quickly to metabolize carbosulfan and used the compound as the carbon and energy sources. As the result, Sp. 7 has the shortest lag phase compare to others. On the day 14th all isolates decreased in cell numbers, except isolate Sp. 1 and Sp. 6 which showed their best growth with the cell numbers were $19 \times 10^{8} \mathrm{CFU} / \mathrm{ml}$ and $12 \times 10^{8} \mathrm{CFU} / \mathrm{ml}$. Meanwhile 
isolate Sp. 7 showed the lowest population, $5.9 \times 10^{8} \mathrm{CFU} / \mathrm{ml}$. Decreasing in cell numbers could be caused by limited available carbon source.

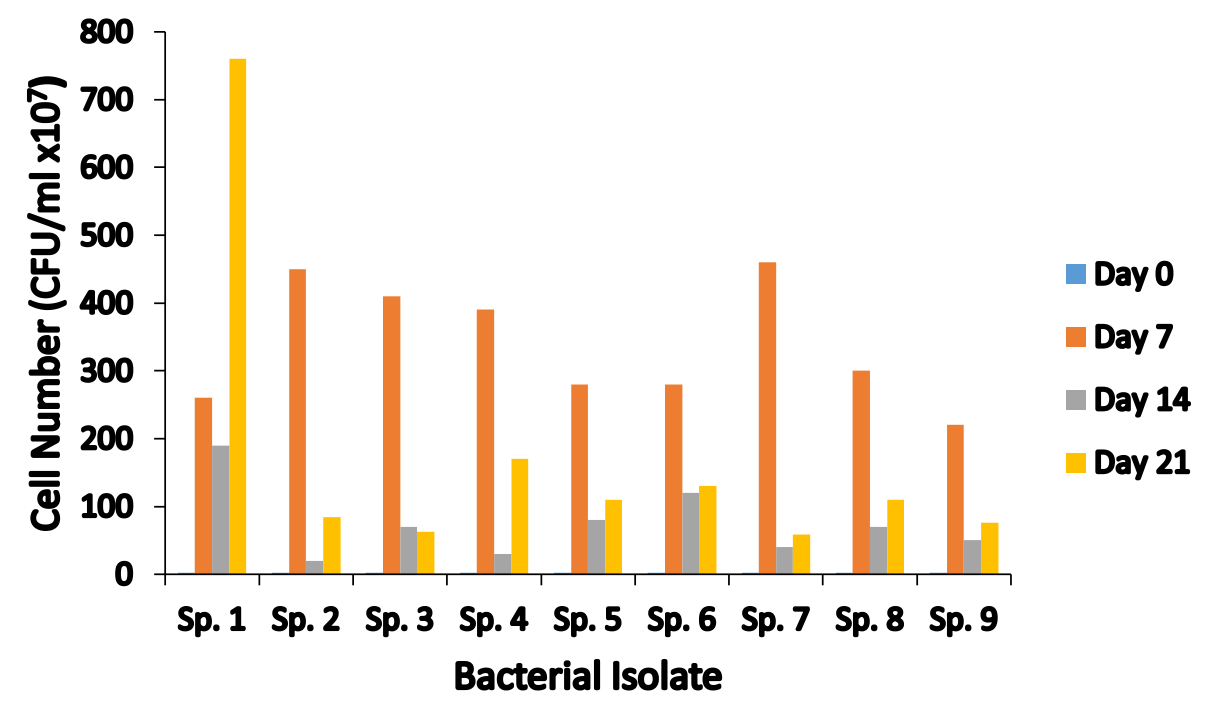

Figure 1. Growth of isolates in BHB medium during 21 days of incubation

Some isolates still able to increase their viable cells on day 21 th, mainly isolates Sp. 4 which increased signicantly. For these isolates, it was assumed that they were able to use carbon source other than carbonsulfan. In addition to active compound, pesticide also contains surfactant that function to increase solubility of active compound in water. This surfactant cold also serve as carbon source. Banat [11] said that biosurfactant-producing bacteria increashe es their metabolism since the biosurfactant secreted on the surface of the cells enhances nutrition transport into the cells and promote their growth rate.

\section{Biosurfactant Activity}

The activity of biosurfactant could examined from its ability to lower surface and interfacial tensions, CMC (critical micelle concentration) and formation of stable emulsion.

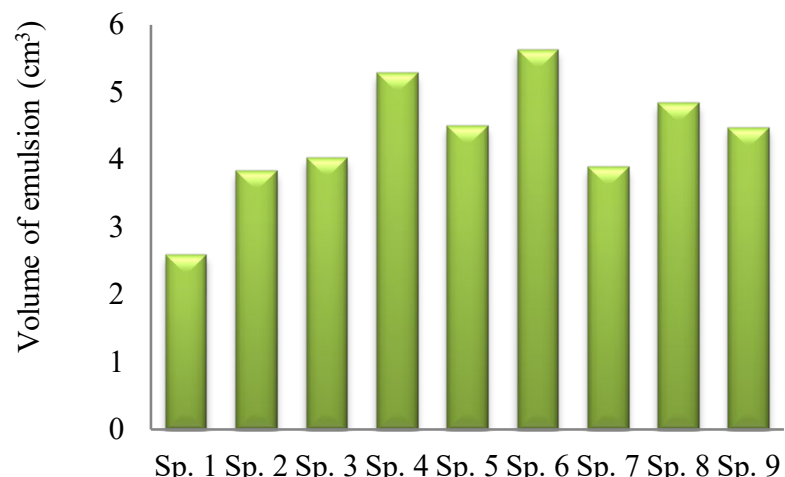

Bacterial Isolates 
Figure 2. Biosurfactant activities of 9 isolates tested.

In this study we observed the formation of stable emulsion. Different biosurfactant activities were shown by all isolates as shown by Figure 2 . The highest biosurfactant activity was shown by isolate Sp. 6 with the emulsion volume was $5.627 \mathrm{~cm}^{3}$ followed by isolate $\mathrm{Sp} .4$ which was $5.273 \mathrm{~cm}^{3}$. Meanwhile isolate Sp. 1 had the lowest activity with emulsion volume $2.582 \mathrm{~cm}^{3}$.

Prak [12] reported that the activity of biosurfactant depend on several factors such as: the structure and composition of biosurfactant, ion strength, the presence and types of additive compounds, and temperature. Isolate Sp. 1 showed the lowest biosurfactant activity despite its highest cell growth $\left(76 \times 10^{8} \mathrm{CFU} / \mathrm{ml}\right)$. On the contrary, isolate $\mathrm{Sp} .6$ which had much less cell number $\left(12 \times 10^{8} \mathrm{CFU} / \mathrm{ml}\right)$ showed the highest biosurfactant activity.

\section{Biosurfactan Production}

All isolates have shown to produce biosurfactant with different yield as well as duration of incubation. In general isolates secretes more biosurfactant as the incubation time is longer, except isolate Sp. 2, Sp. 6 and Sp. 8. The later isolates reached the highest production of biosurfactant on day 7 th and decreased significantly afterward. Isolate Sp. 7 showed the highest biosurfactant concentration on day 14th which was $54.6 \mathrm{ppm}$ and decreased sharply on the day 21th. Meanwhile isolate Sp. 1 showed the lowest yield of biosurfactant which was only 10.4 ppm.

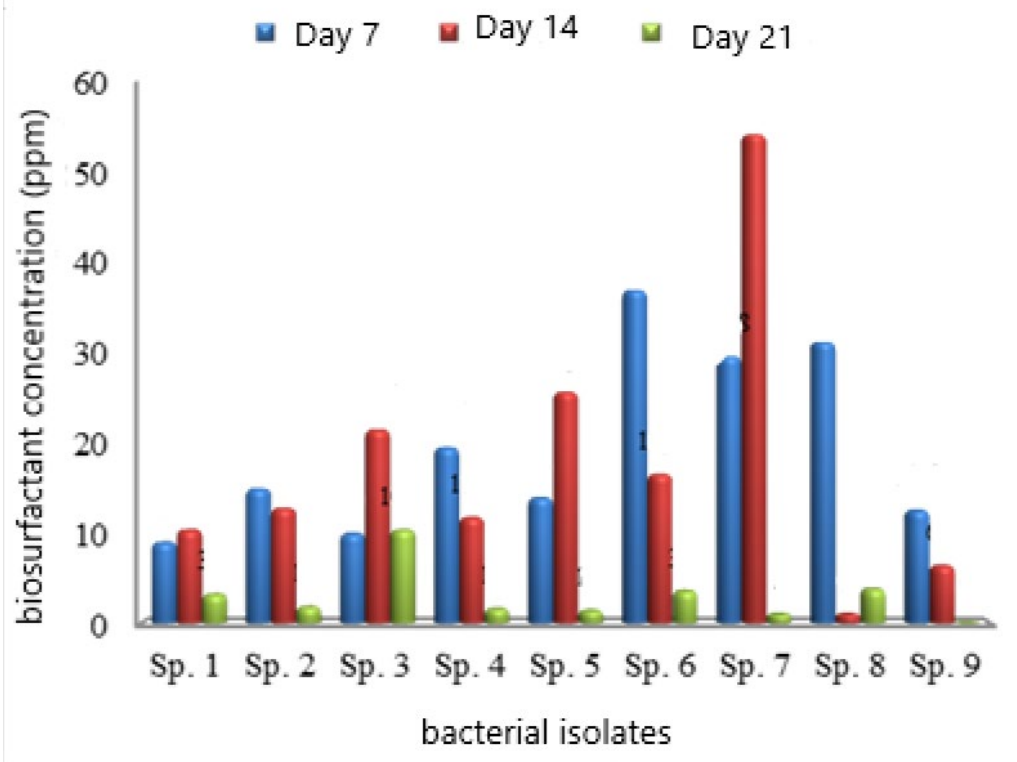

Figure 3. Concentration of biosurfactant produced by isolates.

Compare to the data of bacterial growth which showed that the isolate Sp. 7 grew steadily up to day 7 th of incubation and decreased sharply on day 14th and 21 th, the result seemed to be not correlated. It is likely that the bacteria secreted more biosurfactant up to day 14th to metabolize limited source of substrate. The high population of isolate Sp. 1 produced very less biosurfactant 
compare to others. There are two types of biosurfactant produced by microorganism. First, biosurfactant is secreted into the medium so it could be detected when the supernatant is analyzed. The second type is biosurfactant which is secreted but it still attached to the cell wall, is not released into the medium. The presence of this biosurfactant can't be detected when the supernatant was analized. Rufino [13] reported that $8 \mathrm{~g} / \mathrm{L}$ of crude biosurfactabt could be extracted from Candida lipolitica after 72 hours of incubation and showed a growth-associated production. Another report from Sobrinho [14] said that Candida sphaerica had a biosurfactant yield of $4.5 \mathrm{~g} / \mathrm{L}$ after 144 hours of incubation.

Other factor that affect biosurfactant production is envieonmental condition such as temperature, $\mathrm{pH}$ and salinity. It was assumed that isolate Sp. 7 grew best at $\mathrm{pH} 7$ and secreted more biosurfactant. Other Pseudomonas increased the biosurfactant production as increasing the $\mathrm{pH}$ from 6 to 7 . The the medium $\mathrm{pH}$ higher than 7 the biosurfactant production decreased [15].

\section{Carbosulfan degradation}

Base on above results, growth rate, biosurfactant activity, and the production of biosurfactant, both isolate S.1 and Sp.6 were chosen to be tested on their abilities in degrading carbosulfan. The result showed that the bacteria were able to degrade completely carbosulfan present in medium so no more carbosulfan could be detected on day 21 th. Meanwhile the concentration of carbosulfan in the control reduced $16 \%$ as shown by the following figure.

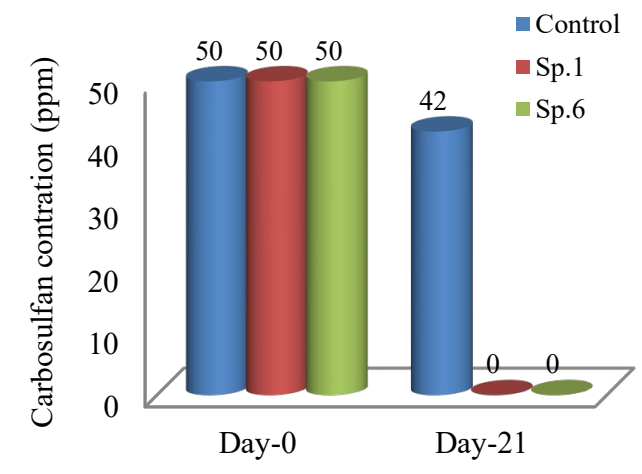

Figure 4. Carbosulfan residue after 21 days of incubation.

Decreasing carbosulfan concentration in control indicated that carbosulfan could be degradaded naturally without participation of microorganism. The presence of light, photooxidation and temperature affect the rate of degradation. In this study, effect of light is excluded since the bacterial cultures were incubated in the dark. It was assumed that naturally, carbosulfan could be degraded very slowly at room temperature.

The ability of both isolate Sp.1 and Sp.6 to degrade carbosulfane completely confirmed with the data about their ability to grow in medium containing carbosulfan as the sole source of carbon and energy. Those isolates showed high activity of biosurfactant and produced enough 
biosurfactant to metabolize carbosulfan completely. Warsito [16] reported that bacterial isolate that produced high concentration of biosurfactant were able to reduce naphthalene concentration up to $94 \%$.

\section{Conclusion}

This investigation clearly indicated that bacterial species isolated from Belawan sea were able to grow and metabolize carbosulfan. The ability of isolates to break down carbosulfan was closely related to the ability of isolates to produce biosurfactant. The biosurfactant was well function to emulsify carbosulfan and promote carbosulfan degradation.

\section{Acknowledgement}

The authors are thankful to the ministry of education for providing fund through Lembaga Penelitian, Universitas Sumatera Utara 2011/2012.

\section{REFERENCES}

[1] Budigunawan, A. N, Analysis of Chlorpyrifos Residue on Alluvial Soil After Planting Shallots In Brebes. [Thesis]. Bogor: Bogor Agricultural Institute. 2004.

[2] Sutamihardja, R.T.M \& M.Rizal. Negative Impact of Pesticide Use on the Environment. Pesticide Analysis Seminar Paper Group. Cisarua. Bogor. 1981.

[3] Tisnadjaja., D. A. Purnama, E. Yudiadi, R. Pujihastuti, C.S. Ibrahim, A. Soeksmanto, D.R. Permana, Suyamto, S.J. Rijadi, Supriatna \& T. Sumardiman. Bioremediation of Pesticide Waste With Indigen Microbes. Biotechnology Research Project Engineering Report. 2001.

[4] Sofia, D. Influence of Pesticides in agricultural environments. USU Digital Library. Medan : University of North Sumatra. 2001.

[5] Muchtar, M. Marine Pollution By Organic Substancepestisida, Polykhlorobiphenyl (PCB) Polyaromatic Hydrocarbons. Surabaya, April 14, 1992.

[6] Bertrand, J. C., P. Bonin, M. Goutx, M. Gauthier \& G. Mile. The Potential Application of Biosurfactant in Combating Hydrocarbon Polution in Marine Environment. Res. Microbiol. 145: 53-56. 1994.

[7] Panjaitan, I.L.WIsolation and Testing potential of Biosurfacant Bacteria From North Sumatra's Belawan Sea in Degrading Naftalen. [Thesis]. Medan: Faculty of MIPA, University of North Sumatra. 2010.

[8] Yunita, Y. Potential Biosurfacant Producing Bacteria from North Sumatra's Belawan Sea in degrading Glyphosate. [Thesis]. Medan: Faculty of MIPA, University of North Sumatra. 2011.

[9] Parra, J. L., J. Guinea, M. A. Manresa, M. Robert, M. E. Mercade, F. Comelles \& M. P. Bosch. Chemical Characterization and Physicochemical Behavior of Biosurfactant. J. Am. Oil Chem. Soc. 66: 141-145. 1989. 
[10] Jain, D. K., D. L. C. Thompson, H. Lee \& J. T. Trevois. A Drop Collapsing Test for Screening Surfactant Producing Microorganism. J. Microbiol. Methods. 13: 271-279. 1991.

[11] Banat, I. M. Biosurfactants Production and Possible Uses in Microbial Enhanced Oil Recovery and Oil Pollution Remediation. A Rev. Bioresource Technol 51: 1-12. 1995.

[12] Prak DJL and Pritchard PH. Solubilization of polycyclic Aromatoc Hydrocarbon mixtures in micellar noionic surfactant solution. Water Res. 36: 3463 - 3472. 2002.

[13] Rufino, RD; Juliana, ML; Galba Maria, CK; and Leoni AS. Characterization and properties of the biosurfactant produced by Candida lipolitica UCP 0988. Electric journal of Biotechnology. 17: 34-38. 2014.

[14] Sobrinho, HBS; Rufino, RD; Luna, JM; Salgueiro AA; Campos-Takaki, GM; and Leite, UFC. Utilization of two agroindustrial by-product for the production of a surfactant by Candida spaerica UCP 0995. Process Biochem. 43:912- 7. 2008.

[15] Guera-Santos, GL; Kapelli, O; and Fiechter, A. Dependence of Psedomonas aeruginosa continuous culture biosurfactant on nutritional and environmental factors. Applied and Environmental Microbiol. 24:443-448. 1986.

[16] Warsito, K. Isolation and Potential of Biosurfacant Producing Bacteria from Sibolga Sea and Tanjung Balai North Sumatra in Degrading Naftalen. [Thesis]. Medan: Faculty of MIPA, University of North Sumatra. 2009. 